\title{
THE EFFECT OF GOAL SETTING AND INTRINSIC MOTIVATION ON TEACHER WORK PERFORMANCE
}

\author{
Url Jurnal: https://uia.e-journal.id/akademika/article/995 \\ DOI : https://doi.org/10.34005/akademika.v10i01.995
}

Submitted: 2020-09-04

\author{
Ania Fitriah \\ Universitas Negeri Jakarta- \\ Indonesia \\ niamentari130792@gmail.com
}

Reviewed: 2021-05-08

Published: 2021-05-30

\author{
Masduki Ahmad \\ Universitas Negeri Jakarta- \\ Indonesia \\ masduki@unj.ac.id
}

\author{
Matin \\ Universitas Negeri Jakarta- \\ Indonesia \\ matin@unj.ac.id
}

\begin{abstract}
The purpose of this research was to study the impact of goal setting and intrinsic motivation on the work performance of teachers in the Sub-District of North Bekasi State Junior High School. This research was conducted using a survey method with path analysis techniques. The population in this study were the civil servant teachers of the State Junior High Schools in North Bekasi District totaling 221 teachers, while the sample in this study was 69 teachers who were randomly selected. The results of this study are as follows; (1) there is a positive direct effect of goal setting on teacher work performance; (2) there is a positive direct effect of intrinsic motivation on teacher work performance, and (3) there is a positive direct effect of goal setting on intrinsic motivation. Therefore, increased work performance can be increased through increased goal setting and strengthening intrinsic motivation in school teachers.
\end{abstract}

Keywords: goal setting, intrinsic motivation, work achievement

\begin{abstract}
Abstrak: Tujuan penelitian ini adalah untuk mengetahui pengaruh penetapan tujuan dan motivasi intrinsik terhadap prestasi kerja guru di SMP Negeri Bekasi Utara Kecamatan. Penelitian ini dilakukan dengan menggunakan metode survei dengan teknik analisis jalur. Populasi dalam penelitian ini adalah 221 guru PNS SMP Negeri di Kelurahan Bekasi Utara, sedangkan sampel dalam penelitian ini adalah 69 guru yang dipilih secara acak. Hasil dari penelitian ini adalah sebagai berikut; (1) terdapat pengaruh langsung yang positif dari penetapan tujuan terhadap prestasi kerja guru; (2) terdapat pengaruh langsung positif motivasi intrinsik terhadap prestasi kerja guru, dan (3) terdapat pengaruh langsung positif penetapan tujuan terhadap motivasi intrinsik. Oleh karena itu, peningkatan prestasi kerja dapat ditingkatkan melalui peningkatan penetapan tujuan dan penguatan motivasi intrinsik pada guru sekolah.
\end{abstract}

Kata Kunci: penetapan tujuan, motivasi intrinsic dan prestasi kerja.

\section{INTRODUCTION}

Teachers as role models in education have a role in improving the quality of education following the expectations and needs of society. As an educator, teachers are required to be able to produce quality students. With this role, they assume, teachers must always try to give their best in carrying out their duties as an educator and as a professional workforce. Schools as organizations where teachers teach are very helpful with how a teacher is performing. This means that the teacher must have good 
quality too so that the students produced are also of quality. The quality of teacher work can be continuously improved by efforts to optimize teacher work performance (Tukilah, Mariah, \& Pardimin, 2018).

Work performance is a very important thing for an organization because achievement reflects the results that have been achieved by employees while working at the organization (Anggraini, Harapan, \& Tahrun, 2020). This means that this work performance is important for schools because it is a reflection of after the teacher's work. Competitive attitudes toward achievement and being innovative and proactive are closely related to performance (Tarmizi \& Soehari, 2015). This means that a teacher's performance is also determined by whatever he wants to do at work. Also, all parties must be involved in increasing the ability of teachers which also affects teacher work performance because this is very important in improving the quality of education in schools (Suhaimi \& Efendi, 2018). This means that not only do teachers try to improve their performance, but all school members also influence it. This is the reason that supportive relationships must be established in the school environment so that teachers can show their maximum work performance.

Work performance is the result achieved by a person in carrying out his work both in quantity and quality through procedures that focus on goals and fulfillment of implementation standards (Wulandari \& Hamzah, 2019). This means that work is not only determined by the amount of work that has been done but well the work that is carried out. Work performance is a combination of three things in work behavior, the potential as an internal factor that supports work behavior, and the job itself (Salju \& Sari, 2020). This means that the achievements produced by these things. Work performance can also be interpreted as a leadership decision on achievement based on quality, timeliness, the number of results, and perceptions of the workload of an individual in an organization (Saweduling, 2013). This means that achievements can also be taken from a leader who is considered guilty of work.

Work performance is the results of work shown by a person in carrying out a task or job that is his responsibility by the applicable rules or regulations. Achievement can only be achieved when a series of attempts are made. According to George and Jones. (2012: 158), explains "performance is an evaluation of the results of a person's behavior". This concept explains that work performance is an evaluation of the results of a person's behavior. So, work performance evaluates and determines how good or bad a person has completed a task or done a job.

Based on these descriptions, it can be synthesized that work performance is the success of a person's work activities. The indicators are the success of completing the task according to the target, innovation in completing tasks, completing tasks according to the expected quality, the desire to work hard, the use of technology in completing tasks.

Indicators that can be used as a measure of work performance are: First, the quality of work, including accuracy and success. Second, the 
quantity of work, which is about output, and it is necessary to pay attention to not only routine output, but also how fast he can finish extra work. Third, dependability includes following instructions, initiative, and being diligent. Fourth, attitudes, namely attitudes towards company employees and work and cooperation. Therefore, the completion of organizational tasks has become an absolute obligation of a teacher in carrying out his job. The implementation of teacher duties is of course adjusted to the job description or job description, by the organizational structure. The details of this task can automatically be a guide for workers in reaching a certain point as expected. The match between the work plan and this target is known as an achievement.

One of the factors that influence work performance is goal setting. When someone has a predetermined goal to achieve, that's when they will devise ways to achieve it. On the other hand, someone who doesn't know his goal will find it difficult to achieve because he doesn't have a basic desire to achieve something. Fang et al. in Subarino et al. state that unclear goals cause employees to be lazy and their work performance is low (Subarino, Ali, \& Ngang, 2012). In this case, the teacher will become lazy in his work when he does not know what goals to achieve. Therefore the leadership needs to determine the goals of its members at work. In general, the more difficult and specific the goals are set, the higher the level of achievement that is produced (Arsanti, 2009). This means that the more specific a person is in setting his goals, the higher his chances of achieving are. This is because the individual already knows what steps he takes in more specific goals so that what must be achieved also becomes clearer. As before, Locke and Latham in Sitanggang et al. state that to encourage one's efforts to achieve achievement is to set specific goals and know what to do (Sitanggang, Mayangsari, \& Zwagery, 2018).

According to Luthans (2011: 183), the goal is "a goal is a performance target that an individual or group seeks to accomplish at work". This concept explains that the definition of a goal is a performance target that an individual or group strives to achieve in the workplace. Furthermore, Luthans added that goal setting is "the process of motivation employees by establishing effective and meaningful performance targets". This concept explains that goal achievement is a process of motivating employees by making effective and meaningful work targets. Goal setting is also a process of motivating employees by building effective and meaningful performance. It provides how organizational behavior should progress from as well as more effective management practices. Goal setting makes employees strive to achieve goals to meet target achievement. Goal setting also provides direction for the nature of employee behavior and guides their thoughts and actions to achieve results as each individual responds and acts according to these intentions or goals.

Goal setting is a cognitive theory with the premise that everyone has a desire to achieve specific results or goals that are expected to be 
achieved (Setiawan, 2017). In this case, goal setting clearly states the participatory goals of all employees in achieving organizational goals and measurable achievement of predetermined targets.

Whereas McShane and Glinow (2010: 146), goal setting is "the process of motivating employees and clarifying their role perceptions by establishing performance objectives". This concept explains that goal setting is the process of motivating employees and clarifying their perceptions of their role by setting performance goals. This goal setting improves employee performance in two ways: (1) by strengthening the intensity and persistence of effort, and (2) by giving employees a clearer perception of roles so that their efforts are channeled toward behaviors that will improve work performance.

Robbins and Coulter (2012: 216), explain the steps for setting goals, namely:

Goal setting involves these steps: review the organization's mission; evaluate available resources; de termine the goals individually or with input from others; write down the goals and communicate them to all who need to know them; and review results and change goals as needed.

This concept explains that goal setting involves the following steps: reviewing the organization's mission, evaluating available resources, determining goals individually or with input from others, writing down goals and communicating to everyone who needs to know them, and reviewing and changing results. purpose required.

The achievement of predetermined goals can be achieved if a teacher has a high motivation to try as much as possible to beat all the challenges faced in the expected work performance, on other hand, teachers who have low motivation will tend to reduce their efforts, give up easily and lack the enthusiasm to achieve work performance high. Therefore, the goal-setting that has been made by the principal should be carried out by teachers with the motivation to achieve work performance.

From some of the opinions above, it can be synthesized that goal setting is the work target carried out by individuals or organizations in the process of motivating employees to determine the desired results. The indicators are making work targets, clarity of assignments, writing work goals, negotiating work targets, identification of facing difficult goals, feedback to reviewing predetermined goals.

Another factor that affects work performance is the teacher's intrinsic motivation. Porter and Lawler in Rahmawati state that employee performance or performance is supported by three factors, namely the level of employee motivation or business factors, ability and clarity, and acceptance of roles (Rahmawati, Hamid, \& Utami, 2013). This means that teacher work performance cannot be separated from motivation within the teacher himself. In this case, the intended motivation is intrinsic. Robbins and Judge in Patty et al. state that intrinsic motivation is a motivation that 
encourages a person to achieve that comes from within the individual or also known as the motivational factor (Patty, Manurung, \& Badawi, 2017). This shows that intrinsic motivation is indeed one of the factors that affect how well a person performs. In other words, good work performance can be achieved when someone's intrinsic motivation or inner motivation is equally good. Because when a person feels that he has a strong desire in himself to excel at work, he will achieve it.

Uno in Rachmatia and Khasanah explained that motivation is an impetus that is contained in a person to try to make changes in behavior that better meet their needs (Rachmatia \& Khasanah, 2019). Motivation is a process that determines the activity, intensity, consistency, and direction of human behavior. Someone is motivated to do something because there is a goal or need to be achieved that will direct one's behavior. One of the motivations that can increase one's achievement is intrinsic motivation or motivation that appears within oneself to achieve certain goals.

Intrinsic motivation stems from the inner drive of a person to do something, inspired by factors like desires, problems, and personal fulfillment. When they think about their jobs, look for the right way to do it, and are full of motivation to do a good job, a person is intrinsically motivated. Intrinsic incentive benefits come from the job they perform themselves, not from external stimuli such as an increase or management recognition.

Intrinsic motivation refers to behavior that is driven by internal rewards. In other words, motivation involves behavior that arises from within the individual because it is intrinsically beneficial. This differs from extrinsic motivation which involves behavior to gain rewards or avoid punishment. Intrinsic motivation occurs when a person acts without a clear external reward and becomes more creative when motivated intrinsically.

Intrinsic motivation occurs when an individual plays an active role in a job because of positive feelings from within that are well-produced, rather than depending on external factors (such as intensive wages or praise from superiors) to motivate to work effectively. Locke (2012: 481), states that "the intrinsic motivation is the motivation to do work because it is interesting, engaging, or positively challenging". Intrinsic motivation is the urge to do work because it is interesting, fun, or positively challenging. The elements that make up intrinsic motivation include a sense of selfdetermination in doing work, a feeling that skills are good for being fully enforced, and a positive feeling about work.

Meanwhile, George and Jones (2011: 159) explain that "intrinsically motivated work behavior is a behavior performed for its own sake, the source of motivation comes from performing the behavior itself in other words". Intrinsically motivated work behavior is behavior that is done for one's own sake, in other words, the source of motivation comes from oneself.

Intrinsic motivation stems from the inner drive of a person to do something, inspired by things like desires, problems, and personal 
satisfaction. When they care for their work, people are intrinsically inspired, look for the right way to do it, and are full of motivation to do it well. Instead of external stimuli such as a promotion or recognition from a boss, the benefits that people get from inherent motivation come from the task itself.

Based on the concepts of intrinsic motivation that have been described, it can be synthesized that intrinsic motivation is the desire that comes from within a person to do something for his benefit. The indicators are interest, ability, effort, and responsibility.

Based on the various facts above, it has shown that teacher work performance is the main aspect of the spearhead of education in achieving educational success in schools. The fact about the low work performance of teachers underlies the importance of a study on the factors that have the potential to influence teacher work performance, including goal setting and intrinsic motivation. Thus, researchers are interested in examining the effect of goal setting and intrinsic motivation on work performance.

\section{METHOD}

This study aims to determine the correct data, facts, and information about the effect of goal setting and intrinsic motivation on the work performance of teachers in Junior High Schools at North Bekasi District. Operationally the objectives of this research can be formulated as follows; 1) To determine the effect of goal setting on work performance, 2) To determine the effect of intrinsic motivation on work performance, 3) To determine the effect of goal setting on intrinsic motivation. The research method used in this research is quantitative research in which the results of the research will be in the form of numbers which are then described. The research design in this study was a survey and used path analysis techniques to determine the effect of the variables. Data collection was carried out using a questionnaire which was then applied in the form of google form. The population in this study was 221 civil servant teachers of SMP Negeri in North Bekasi District. The sample in this study was 69 selected based on a simple random sampling technique (simple random sampling). The data obtained were then tested using the normality and linearity test.

\section{RESULTS}

Based on the results of the calculation of the normality test (the complete calculation is in attachment 5), the following results are obtained:

\section{a. Normality Test for Estimated Regression Error $\mathbf{X}_{3}$ over $\mathbf{X}_{1}$}

Based on the calculation results, the value of $L_{\text {count }}=0.057$, this value is smaller than the value of $L_{\text {table }}(n=69 ; \alpha=0.05)$ of 0.107 . Considering that the $L_{\text {count }}$ value is smaller than $L_{\text {table, }}$ the distribution 
of work performance data for goal setting tends to form a normal curve.

b. Normality Test for Estimated Regression Error $\mathrm{X}_{3}$ over $\mathrm{X}_{2}$

Based on the calculation results, the value of $L_{\text {count }}=0.057$, this value is smaller than the value of $L_{\text {table }}(n=69 ; \alpha=0.05)$ of 0.107 . Given that the $L_{\text {count }}$ value is smaller than $L_{\text {table, the distribution of work }}$ performance data on intrinsic motivation tends to form a normal curve.

c. Normality Test for Estimated Regression Error $\mathrm{X}_{\mathbf{2}}$ over $\mathbf{X}_{\mathbf{1}}$

Based on the calculation results, the value of $L_{\text {count }}=0.059$, this value is smaller than the value of Ltable $(n=69 ; \alpha=0.05)$ of 0.107 . Considering that the $L_{\text {count }}$ value is smaller than $L_{\text {table, the distribution }}$ of intrinsic motivation data on goal setting tends to form a normal curve.

Based on the value above, it can be concluded that the null hypothesis $(\mathrm{HO})$ can be stated that the sample comes from a normally distributed population and cannot be rejected, in other words, that all selected samples come from a normally distributed population. The recapitulation that has been done can be seen in the table as follows:

Table 1 Results of Normality Test for Estimated Regression Error

\begin{tabular}{cccccc}
\hline \multirow{2}{*}{$\begin{array}{c}\text { Estimated } \\
\text { Regression Error }\end{array}$} & $\mathrm{n}$ & \multirow{2}{*}{$\mathrm{L}_{\text {count }}$} & \multicolumn{2}{c}{ Ltable $^{*}$} & \multirow{2}{*}{ Information } \\
\cline { 4 - 5 } $\mathrm{X}_{3}$ over $\mathrm{X}_{1}$ & 69 & 0.057 & 0.107 & 0.124 & Normal \\
\hline $\mathrm{X}_{3}$ over $\mathrm{X}_{2}$ & 69 & 0.057 & 0.107 & 0.124 & Normal \\
\hline $\mathrm{X}_{2}$ over $\mathrm{X}_{1}$ & 69 & 0.059 & 0.107 & 0.124 & Normal \\
\hline
\end{tabular}

Based on the values of the $\mathrm{L}_{\text {count }}$ and $\mathrm{L}_{\text {table }}$ above, it can be concluded that the pairs of all data, both work performance on goal setting, work performance on intrinsic motivation, and intrinsic motivation for goal setting come from samples that are normally distributed.

While the results of the significance and linearity regression tests are as follows:

Table 2 Results of Significance Test and Regression Linearity Test

\begin{tabular}{|c|c|c|c|c|c|c|}
\hline \multirow[b]{2}{*}{ Reg } & \multirow[b]{2}{*}{ Equation } & \multicolumn{2}{|c|}{ Regression test } & \multicolumn{2}{|c|}{ Liniearity test } & \multirow[b]{2}{*}{ Conclusion } \\
\hline & & $F_{\text {count }}$ & $\begin{array}{c}F_{\text {table }} \\
\alpha=0.01\end{array}$ & $F_{\text {count }}$ & $\begin{array}{c}F_{\text {table }} \\
\alpha=0.05\end{array}$ & \\
\hline $\begin{array}{c}\mathrm{X}_{3} \\
\text { over } \\
\mathrm{X}_{1}\end{array}$ & $\hat{\mathbf{X}}_{3}=18.86+0.773 \mathrm{X}_{1}$ & $\underset{* *}{31.12}$ & 7.03 & $1.29 \mathrm{~ns}$ & 1.78 & $\begin{array}{l}\text { Very significant } \\
\text { regression / } \\
\text { Linear } \\
\text { regression }\end{array}$ \\
\hline $\begin{array}{c}\mathrm{X}_{3} \\
\text { over } \\
\mathrm{X}_{2}\end{array}$ & $\hat{\mathbf{X}}_{3}=21.05+0.772 \mathrm{X}_{2}$ & $\underset{* *}{43.06}$ & 7.03 & $0.91^{\mathrm{ns}}$ & 1.79 & $\begin{array}{l}\text { Very significant } \\
\text { regression / } \\
\text { Linear } \\
\text { regression }\end{array}$ \\
\hline $\begin{array}{c}\mathrm{X}_{2} \\
\text { over } \\
\mathrm{X}_{1}\end{array}$ & $\hat{\mathbf{X}}_{2}=37.45+0.695 \mathrm{X}_{1}$ & $\underset{* *}{40.52}$ & 7.03 & $1.05 \mathrm{~ns}$ & 1.78 & $\begin{array}{l}\text { Very significant } \\
\text { regression / } \\
\text { Linear } \\
\text { regression }\end{array}$ \\
\hline
\end{tabular}

Keterangan :

** $\quad$ : Very Significant 


\section{DISCUSSION}

The following is a discussion of the research findings as an effort to synthesize theoretical studies and empirical results, judging from the literature review that has been discussed and the empirical analysis above. The discussion of the outcomes of the research hypothesis study and testing is defined in depth as follows:

\section{The Effect of Goal Setting on Work Performance}

On the basis of testing the first hypothesis, it can be concluded that the Target Setting has a positive direct effect on work performance with a coefficient of correlation value of $\mathrm{r} 13=0.563$ and a coefficient of path value of $p 31=0.288$. This suggests that the setting of goals has a positive direct influence on work performance.

The outcomes of this analysis are close to the research conducted by Han and Lu in their research entitled "A Correlation Study among Achievement Motivation, Goal-Setting and L2 Learning Strategy in EFL Context". The study concluded that there is a significant positive relationship between achievement motivation and goal setting with aspects of motivation for success and three levels of goal setting (Han \& Lu, 2017). This shows that someone whose goals have been set will strive to excel in their work. When someone has definite goals and motivation for achievement, they will try to achieve maximum results in their work. In line with the performance that will get better later, the work performance will also be higher.

The results of this study are also by the opinions of several experts as follows:

According to Locke (2012: 56), also mentioning the theory of goal setting and work performance, "thousands of laboratories and field studies were conducted in a wide variety of settings using many different tasks demonstrating that the effects of goal setting on performance are positive, potential, and robust ". This theory suggests that the thousands of laboratory and field studies carried out in a variety of settings using many different tasks suggest that the effect of goal setting on work performance is positive, present, and strong.

From the description above, it can be concluded that goal setting can positively, effectively, and strongly influence work performance to improve work performance in a better direction.

\section{The Influence of Intrinsic Motivation on Work Performance}

It can be summarized that there is a positive direct influence of Intrinsic Motivation on Work Performance with a correlation coefficient value of $r 23=0.626$ and a path coefficient value of $p 32=0.449$ based on 
testing the second hypothesis. This means that the direct impact of Intrinsic Motivation on Work Performance is direct.

The findings of this study are consistent with the analysis carried out by Patty et al. entitled "The Influence of Organizational Culture, Intrinsic Motivation, and Extrinsic Motivation on Employee Performance at PT. Bringin Srikandi Finance "where the results of his research found that intrinsic motivation has a positive and significant effect on employee work performance at PT Bringin Srikandi Finance (Patty, Manurung, \& Badawi, 2017). Someone who already has inner motivation will certainly have the desire to excel at work. In this case, teachers who have high intrinsic motivation will try to improve their performance at work. Motivation in a teacher is very important and must be considered because if they don't have it, not only will they not be able to perform well at work, but their performance will also decline.

Putri in Widyaputra and Dewi stated that motivation from themselves (intrinsic) and the leadership will facilitate the work of an employee so that company goals can be achieved properly and employee performance increases (Widyaputra \& Dewi, 2018). This indicates that intrinsic motivation is as important as extrinsic motivation. When a person has motivation from within himself and motivation from the people and the environment around him, then he will want to achieve something maximally. His enthusiasm will increase with these impulses and his goals will be more easily achieved accompanied by his efforts to achieve these goals.

This is also by the opinion of Miner (2015: 33), "the intrinsic motivation is defined as based on the desire for competence and selfdetermination." Intrinsic motivation is defined as the basis for the desire to be competent and self-determination. For example, by providing choices about what to do. done or what orders to do in tasks, the use of feedback. Extrinsic rewards, such as money has both a controlling aspect and an information aspect. If the control aspect is important, intrinsic motivation decreases. If information or feedback is important and positive, then intrinsic motivation This theory explains that much intrinsic motivation provides considerable support and influence on work performance, as well as a better understanding of the main effect of intrinsic motivation on work performance. From the description above it can be concluded that intrinsic motivation has a major influence, sufficient big, and important in giving the understanding of the task in improving work performance towards a better direction in the success of completing tasks to achieve the organizational goals that have been set. Intrinsic motivation also has a direct positive effect on work performance.

\section{The Effect of Goal Setting on Intrinsic Motivation}

Based on testing the third hypothesis, it can be concluded that there is a positive direct effect of Goal Setting on Intrinsic Motivation with a correlation coefficient of $r 21=0.614$ and a path coefficient value of $p 21$ 
$=0.614$. This means that Goal Setting has a direct effect on Intrinsic Motivation.

In her research, Lutfianawati stated that setting good goals will lead to high intrinsic motivation as well (Lutfianawati, Nugraha, \& Rachmahana, 2014). This shows that the better a person is at setting his goals, the higher his intrinsic motivation will also be. When a person has set goals for work, he will have the desire to achieve them. This desire is part of the intrinsic motivation that comes from within a person. The more specific a person's goals are set, the higher the intrinsic motivation will be. This is also by the opinion of McShane and Glinow (2010: 48), that goal setting is "the process of motivating employees and clarifying their role perceptions by establishing performance objectives". This theory explains that goal setting is the process of motivating employees and clarifying their perception of their role by setting performance goals, let alone self-motivation as a seriousness for something to be achieved.

Based on the above explanation, it can be concluded that there is a positive influence on goal setting and intrinsic motivation. This is indicated by the beneficial effect of goal setting on intrinsic motivation in the presence of employee motivation to achieve predetermined goals and reluctance to leave or reduce assigned tasks by the role in the organization so that each individual can carry out tasks following their duties and roles in the organization.

The path analysis model can be seen in the following figure:



Figure 1. Empirical Model Between Variables 


\section{CONCLUSION}

Based on the results of testing the proposed research hypothesis, it is proven that: 1) Goal setting has a positive direct effect on work performance. This means that the increase in goal setting has resulted in an increase in the work performance of teachers at SMP Negeri in North Bekasi District. 2) Intrinsic motivation has a positive direct effect on work performance. This means that the increase in intrinsic motivation results in an increase in the work performance of teachers at SMP Negeri in North Bekasi District. 3) Goal setting has a positive direct effect on intrinsic motivation. This means that an increase in goal setting results in an increase in Intrinsic Motivation for SMP Negeri teachers in North Bekasi District.

Steps that can be taken to increase goal setting and increase intrinsic motivation include the following: 1) Increasing teamwork in the school environment, this effort can be carried out by communicating well among school members and through intensive work coordination between the principal and teachers, especially in the implementation of creative learning, 2) In making decisions for teachers to be included, this effort can be made in determining the duties of teachers in schools and receiving input from the school committee related to the work of teachers, 3) Increasing the discipline of teachers in the school environment, this effort can be done by motivating the teachers to carry out their duties seriously and giving awards so that carrying out their main tasks and functions can be carried out properly, 4) Evaluation of teamwork, this effort is made to improve the performance of teachers which can affect work performance, 5) Carrying out education and training activities, this effort can be done by carrying out training activities to increase the intrinsic motivation of teachers carried out by internal schools and the education office, 6) Developing a culture of learning enthusiasm for teachers, this effort can be carried out through activities in the field of religion and training or training for school teachers to improve work performance and, 7) Forming a learning team between teachers, this effort can be done by learning activities with each class teacher at a certain level as well as teachers in the field of study, so that teachers can mutually motivate one another and have a common vision in carrying out tasks at school.

\section{REFERENCES}

Anggraini, E., Harapan, E., \& Tahrun. (2020). Pengaruh Tunjangan Sertifikasi dan Komitmen pada Tugas terhadap Prestasi Kerja Guru. Jurnal Manajemen Pendidikan : Jurnal Ilmiah Administrasi, Manajemen dan Kepemimpinan Pendidikan, 2(1), 61-91.

Arsanti, T. A. (2009). Hubungan antara Penetapan Tujuan, Self-Efficacy dan Kinerja. Jurnal Bisnis dan Ekonomi (JBE), 16(2), 97-110. 
George, Jennifer M. dan Jones Gareth R. 2011. Understanding and Managing Organizational Behavior Sixth Edition, New Jersey: Prentice Hall.

Han, J., \& Lu, Q. (2017). A Correlation Study among Achievement Motivation, Goal-Setting and L2 Learning Strategy in EFL Context. English Language Teaching, 11(2), 5-14. doi: 10.5539/elt.v11n2p5.

Locke, Edwin A. 2012. Handbook of Principles of Organzational Behavior, UK: John Wiley and Sons Ltd.

Lutfianawati, D., Nugraha, R. P., \& Rachmahana, R. S. (2014). Pengaruh Pelatihan Goal Setting terhadap Motivasi Belajar Bahasa Inggris Siswa. Jurnal Intervensi Psikologi, 6, 125-138.

Luthans, Fred. 2011. Organizatinal Behavior, Eleventh Editions, Boston: McGraw Hill.

McShane, Steven L. dan Glinow, Mary Ann Von. 2010. Organizational Behavior, USA: McGraw Hill.

Miner, John B. 2015. Organizational Behavior 2: Essential Theories of Process and Structure 1st Edition, Kindle Edition, New York: Routledge.

Patty, G. Y., Manurung, A. D., \& Badawi, A. (2017, September). Pengaruh Budaya Organisasi, Motivasi Intrinsik dan Motivasi Ekstrinsik terhadap Prestasi Kerja Karyawan pada PT. Bringin Srikandi Finance. Jurnal SWOT, VII(3), 506-522.

Rachmatia, A. N., \& Khasanah. (2019). The Relationship Between EJournal Utilization and Learning Motivation with Library Knowledge Abilities. Akademika : Jurnal Teknologi Pendidikan, 8(2), 84-104. doi: 10.34005/akademika.v8i02.

Rahmawati, A. H., Hamid, D., \& Utami, H. N. (2013). Pengaruh Disiplin Kerja dan Kemampuan Kerja terhadap Prestasi Kerja Karyawan. Jurnal Administrasi Bisnis (JAB), 6(2), 1-9.

Robbins, Stephen P, dan Coulter, Mary. 2012. Management Eleventh Edition, New Jersey: Prentice Hall.

Salju, S., \& Sari, H. (2020). Statistical Analysis of Work Achievement from Employee Motivation. International Journal of Control and Automation, 13(2), 917-922.

Saweduling, P. (2013). Motivasi Kerja, Kompensasi, Pelatihan dan Pengembangan, Karakteristik Pekerjaan terhadap Prestasi Kerja Guru SMP di Kabupaten Kepulauan Talaud. Jurnal EMBA : Jurnal Riset Ekonomi, Manajemen, Bisnis dan Akuntansi, 1(4), 582-595. doi: 10.35794/emba.v1i4.2739.

Setiawan, N. A. (2017). Pengaruh Pelatihan Penetapan Tujuan (Goal Setting) Untuk Meningkatkan Motivasi Belajar Agama Islam pada Mahasiswa. Al-Adyan : Jurnal Studi Lintas Agama, 12(1), 31-51.doi: 10.24042/ajsla.v12i1.1443.

Sitanggang, N. G., Mayangsari, M. D., \& Zwagery, R. V. (2018, Februari). Hubungan antara Penetapan Tujuan dengan Motivasi Berprestasi 
pada Siswa SMK Negeri 1 Martapura. Jurnal Kognisia, 1(1), 17-22. doi: 10.20527/jk.v1i1.1381.

Subarino, Ali, A. J., \& Ngang, T. K. (2012). Penetapan Tujuan dan Keadilan Organisasi Serta Dampaknya terhadap Efektivitas Sekolah : Sebuah Kajian Eksplorasi. Jurnal Manajemen Pendidikan, VIII(1), 52-66.

Suhaimi, \& Efendi, N. (2018). Hubungan peran kepala sekolah dan sikap terhadap profesi guru dengan prestasi kerja guru SMA negeri di kabupaten Hulu Sungai Selatan. Lentera Jurnal Pendidikan, 13(1), 73-83. doi: 10.33654/jpl.v13i1.350.

Tarmizi, A., \& Soehari, T. D. (2015). Pengaruh antara Pengambilan Risiko, Bersiang Agresif Mengejar Prestasi, Inovatif, Kepuasan Kerja dan Kecerdasan Entrepreneurial (Studi pada Perwira Menengah di Markas Besar Tentara Nasional Indonesia Angkatan Laut-Jakarta). Akademika : Jurnal Teknologi Pendidikan, 4(2), 108-129.

Tukilah, Mariah, S., \& Pardimin. (2018). Kontribusi Kompensasi, Efikasi Diri, dan Budaya Organisasi Terhadap Prestasi Kerja Guru SD. Media Manajemen Pendidikan, 1(2), 206-216. doi: 10.30738/mmp.v1i2.3254.

Widyaputra, I. A., \& Dewi, A. K. (2018). Pengaruh Motivasi Intrinsik terhadap Kepuasan Kerja dan Kinerja Karyawan pada PT Bussan Auto Finance. E-Jurnal Manajemen Unud, 7(1), 85-104. doi: 10.24843/EJMUNUD.2018.v7.i01.p04 .

Wulandari, A., \& Hamzah, R. (2019, September). Dampak Disiplin Kerja dan Kemampuan Kerja terhadap Prestasi Kerja Karyawan. Jurnal Signaling: Jurnal Manajemen \& Bisnis, 8(2), 41-47 